\title{
Antična steklarska proizvodnja na območju jugovzhodnih Alp in vzhodnega Jadrana
}

\author{
Irena Lazar \\ UP FHŠ, Oddelek za arheologijo in dediščino ter Inštitut za arheologijo in dediščino \\ irena.lazar@fhs.upr.si
}

\section{Uvod}

Specialistične raziskave antičnega stekla samostojno ali v sklopu novih arheoloških odkritij in raziskav prinašajo vedno nove rezultate (Nenna 2008; Fünfschilling 2015). Primerjave novih izsledkov v mednarodnem prostoru $s$ stanjem raziskav pri nas omogočajo drugačno ali natančnejše ovrednotenje nekaterih do sedaj znanih dejstev ali hipotez. Prav je, da v tem kontekstu ponovno osvetlimo stanje raziskav antične steklarske proizvodnje našega področja in bližnjega sosedstva.

\section{Prazgodovina}

Najstarejše najdbe steklenih predmetov z območja JV Alp poznamo iz obdobja kulture žarnih grobišč. Grob 289 iz Dobove, datiran v 11. stoletje pr. n. š., vsebuje najstarejšo pri nas poznano stekleno jagodo (Stare 1975, tab. 41, 3). V mlajših grobovih kulture žarnih grobišč, v času 9. in 8. stoletja pr. n. š., postanejo steklene najdbe pogostejše in $\mathrm{v}$ grobovih večkrat najdemo priložene steklene jagode oz. ogrlice. Priložene jagode v teh grobovih so najprej zelo majhne (pr. o,4-o,6 cm), večinoma modre in bele barve. Sčasoma pa se $\mathrm{v}$ številnih grobovih iz obdobja prehoda bronaste $\mathrm{v}$ železno dobo na najdišču Mestne njive v Novem mestu pojavljajo tudi večje modre jagode, okrašene z belimi ali rumenimi očesci (Križ 1995, tab. 57: 113; Križ in Turk 2003, 89). 
V starejši železni dobi doživi stekleno okrasje v slovenskem in evropskem prostoru izreden razcvet $\mathrm{v}$ barvah in oblikah, prav tako pa se $\mathrm{v}$ tem času pri nas pojavijo prve steklene posode. Steklene jagode so običajno nanizane v dolge ogrlice, najdemo jih tudi našite na oblačilih. Jagode so okrogle, sodčaste, cevaste, oblikovane kot košarice, ovnove glavice ali ptice, nekatere imajo celo železne zanke za obešanje (Križ 1997, 38 spodaj). Barvne kombinacije so zelo pestre, okrasni motivi obsegajo valovnice, pike, linije cik-cak, očesca in aplike drugobarvnega stekla (Haevernick 1974, 61; Križ in Turk 2003, 91, št. 19, 98-99). V gomili I iz Stične je bilo npr. najdenih 20.500 steklenih jagod, prav tako bogat pa je bil grob z Magdalenske gore, v katerem pa so našteli le 7.310 steklenih jagod (Haevernick 1974, 62). S steklom so bile okrašene in olepšane tudi nekatere okrasne zaponke - fibule. Med njimi so še posebej zanimive fibule ježevke, najdene npr. na Magdalenski gori, v Vačah, na Brezju in Šmarjeti (Haevernick 1959, Taf. 1: 1-8). Lok teh fibul ima na bronastem žičnatem jedru obloge, oblikovane iz prozornega modro-zelenkastega stekla, z ježastimi aplikacijami. Oblogi iz temno modro obarvanega stekla, ki krasita fibuli iz Boštanja, sta okrašeni s steklenimi nitmi v kontrastni rumeni barvi, raztegnjenimi v motiv cik-cak in $\mathrm{z}$ jagodami v obliki očesc (Haevernick 1959, Taf. 2, 8-9). Spet drugače sta izdelana loka fibul iz Rovišča, kjer je steklo jantarne barve v obliki spirale ovito okrog jedra, na sredini pa okras dopolnjujejo še steklene bunčice (Haevernick 1959, Taf. 2, 5-7). Fibule s stekleno oblogo se pojavljajo predvsem v 6. st. pr. n. š. (Gabrovec 1987, 49).

Izjemen pojav $\mathrm{v}$ grobovih jugovzhodnoalpskega prostora so tudi majhne posodice $z$ vertikalnimi rebri na ostenju. Gre za izdelke, narejene v kalupu, ki so jim nato naknadno narebrili ostenje (Haevernick 1958, 14; 1974, 65). V Sloveniji jih poznamo v 5. stoletju pr. n. š. v Mostu na Soči in Črnolici pod Rifnikom (Haevernick 1958, Taf. 1: 4-5; 2; 3: 1, 2; Lazar 2004, 49, kat. 4). Izdelane so iz naravno obarvanega, rahlo zelenkastega stekla, obarvanega stekla jantarno rjave barve ali iz modro obarvanega stekla $\mathrm{v}$ različnih odtenkih. Predvsem modre skodelice so pogosto okrašene $\mathrm{z}$ nitmi drugobarvnega stekla v ravnih ali linijah cik-cak. Posodice iz Mosta na Soči imajo tudi presegajoč, narebren ročaj (Haevernick 1958, Taf. 2: 3-6). Nekateri avtorji so domnevali, da so bile skodelice namenjene shranjevanju kozmetičnih proizvodov; glede na velikost in izdelavo ustja lahko potrdimo, da niso bile pripravne za pitje, prej za zajemanje tekočin.

Razvejani trgovski stiki kultur starejše železne dobe jugovzhodnega alpskega prostora s svetom zahodnih in sredozemskih kultur se ne odraža- 
jo le v izbranih importih kovinskih in keramičnih izdelkov, ampak tudi v steklenem gradivu. Mednje sodijo posodice, izdelane na jedru, izdelki steklarskih delavnic v Sredozemlju. Skoraj v celoti ohranjena posodica je bila najdena v Stični (Kastelic 1960, t. 3: 2). Dvoročajna modra steklenička (amforiskos) je po ostenju okrašena $\mathrm{z}$ večbarvnimi nitmi stekla v motivu cik-cak, ki ga dopolnjujejo linije po vratu in ramenu. Odlomke enakih izdelkov poznamo tudi iz gomile v Šmarjeti (Dular 1991, t. 29: 26-28). V obeh primerih gre po analogijah za izdelke sredozemskih delavnic od konca 6. do začetka 4. stoletja (Harden 1981, 77, pl. 11: 175-90).

\subsection{Vprašanje lokalne proizvodnje}

Izredno pestra paleta steklenih jagod in ostalih okrasnih predmetov v starejši železni dobi, s številnimi izvirnimi oblikami, barvami in okrasi, najdenimi samo na tem prostoru, ponuja domnevo, da so tu morda delovale steklarske delavnice. Na to možnost je prva opozorila T. E. Haevernick, ki je preučevala jagode s slovenskih najdišč $(1974,65)$, in njena hipoteza je bila nato večkrat povzeta. Nove in številne najdbe, predvsem iz gomil na Kapiteljski njivi v Novem mestu (Križ 1997; Križ in Turk 2003), so v zadnjih desetletjih paleto barv in oblik steklenih jagod iz starejše železne dobe še obogatile.

Prav zaradi tega bi se zdela domneva o lokalni proizvodnji toliko verjetnejša. Žal pa imamo zaenkrat v celoti raziskanih predvsem veliko grobišč. Raziskanost prazgodovinskih naselbin, kjer bi lahko odkrili sledove steklarske obrti, je precej skromnejša. Poleg tega za izdelavo jagod zadošča že peč majhnih dimenzij; odpadkov je malo, zato je verjetnost, da bi odkrili ostanke take peči, majhna.

Poznavanje značilnosti steklarske proizvodnje, postopkov taljenja surovin za pridobivanje surovega stekla in trgovine s steklenimi ingoti že od bronaste dobe dalje (Bass 1986, 289) pa ponuja še nekaj prepričljivejših odgovorov. Najverjetneje je, da je steklo kot surovina v naše kraje oziroma halštatska središča prišlo kot import ali rezultat trgovske izmenjave in je tu tekla le proizvodnja jagod. Druga možnost so tudi potujoči obrtniki, ki so se selili iz kraja v kraj, postavili peč in v času bivanja na izbrani lokaciji zadostili potrebam, željam in okusu prebivalcev posameznih naselbin in morda tudi njihovih sosed. Kakovost izdelave steklenih jagod iz Novega mesta, okrasje in posebne oblike brez dvoma pričajo o izkušenih mojstrih, ki so odlično obvladali svojo obrt. Jagode bi bile lahko izdelane tudi v delavnicah izven našega ozemlja, vendar po naročilu in okusu odjemalcev oz. kupcev. 
Morda so ponekod služile celo kot neke vrste plačilno sredstvo. Taki primeri so poznani v srednjeveški steklarski industriji (Calvi di Coenzo 1996, 10).

V zadnjem času je analiza nekaterih oblik steklenih jagod, značilnih za negovski horizont, npr. amforic iz brezbarvnega stekla, pokazala, da gre brez dvoma za uvožene izdelke z območja Makedonije (Blečić Kavur in Kavur 2017, 101); tam so steklarske delavnice proizvajale raznolike in izjemno kakovostne izdelke iz brezbarvnega stekla za elito po postopku, ki so ga poznali že stari Asirci, nato pa se je preko Male Azije razširil in uveljavil tudi v Makedoniji (Ignatiadou 2016, 132, 136, Fig. 4). Razprostranjenost teh miniaturnih amforic, ki niso imele le okrasnega, ampak tudi apotropejski pomen, odraža široko razvejane stike sredozemskih centrov tudi s prazgodovinskim svetom JV evropskih ter balkanskih kultur v teku 4. stoletja pr. n. š. (Blečić Kavur in Kavur 2017, 107, sl. 4; Rustoiu 2015, 367, sl. 3). Te izmenjave odražajo na eni strani trgovino na dolge razdalje in na drugi socialne stike vrhnjega sloja, ki je z izmenjavo daril in eksogamijo potrdil politične, socialne in gospodarske zveze oz. zaveze (Rustoiu 2015, 372).

Še več pa nam o izvoru surovin in izdelkov povedo arheometrične analize. Te je v okviru svoje doktorske disertacije opravila Ana Franjić in prve izsledke predstavila na kongresu leta 2018 v Carigradu (Franjić idr. 2020) in najnovejše spomladi 2020 na simpoziju v Kopru. ${ }^{1}$ Rezultati analiz so pokazali več skupin glede na sestavo stekla; kobaltno modro lahko vzporejamo z izdelki iz Nimruda v Mezopotamiji in iz Francije, skupina stekla, narejena $z$ egipčanskim natronom, pa ustreza t. i. skupini levantinskega stekla (Franjić idr. 2020, 56). Ti rezultati kažejo, da je steklo v starejši železni dobi v te kraje prihajalo kot import in rezultat trgovine na dolge razdalje, kot surovo steklo in/ali kot izdelki. Če so slednje deloma izdelovali tudi na Dolenjskem, pa ostaja še brez odgovora.

Dokler nimamo neposrednih dokazov za izdelavo jagod v prazgodovinskih naselbinah, ostaja ideja o lokalni proizvodnji le hipoteza. Vse več pa je dokazov, da so surovine in izdelki prihajali $\mathrm{k}$ nam $\mathrm{v}$ okviru trgovine in tudi kot izmenjava daril med elito.

\section{Rimska doba}

Rimska doba in razširitev rimske oblasti na obravnavano območje je skupaj z vsemi drugimi dosežki rimske civilizacije prinesla tudi novosti in na-

Simpozij ARTE-FACTUM - Study Days on Ancient Glass je potekal med 6. in 8. marcem 2020 na UP FHŠ v Kopru, prispevki so v pripravi za objavo. 
predek v steklarski obrti, ki je v helenizmu in obdobju republike razvila številne novosti in tudi nove tehnike. Nobenih dokazov ni, da bi se prazgodovinska tradicija, povezana $\mathrm{z}$ uporabo stekla, nadaljevala $\mathrm{v}$ rimski čas. V teku 1. stoletja pr. n. š. in 1. stoletja n. š. so trgovske poti steklenih izdelkov do naših krajev vodile pretežno preko severne Italije (Lazar 2006a, 331). Glavni trgovski center oz. emporij za področje JV Alp, Panonije in Balkana je bila Akvileja; tu so se zbirali izdelki iz severnoitalskih delavnic pa tudi iz drugih centrov osrednje Italije. Redki dragoceni izdelki so prihajali tudi iz delavnic vzhodnega Sredozemlja in Egipta.

Neposredne povezave s severnoitalskimi in akvilejskimi delavnicami dokazujejo tudi na naših najdiščih odkriti izdelki, ki izvirajo iz teh delavnic (slika 1). Odlomek dna večje pravokotne steklenice $z$ odtisom oz. napisom Sentia Secunda iz Akvileje je bil najden v naselju oz. obcestni in carinski postaji Romula (Ribnica pri Jesenicah na Dolenjskem; Lazar 2005, 41; 2020). Delno ohranjen napis lahko primerjamo z dvema v celoti ohranjenima steklenicama iz groba v Linzu (Schwanzar 2003, 333, sl. 2). Napis oz. odtis na dnu v treh vrsticah (SENTIA SECVNDA FACIT AQ(vileia) VITR(earia)) je odlično ohranjen in ga lahko prevedemo kot »izdelala Sentija Sekunda iz Akvileje«. Na osnovi primerjav lahko potrdimo, da je odlomek dna iz Romule prav tako pripadal dvoročajni steklenici, ki je nosila napis steklarke ali lastnice steklarske delavnice Sentie Sekunde iz Akvileje. Prvotno so napis oz. odtis interpretirali kot ime lastnice steklarske delavnice, saj naj bi bilo pihanje stekla prezahtevno, da bi ga lahko obvladala ženska (Calvi 1969, 12-13). Danes seveda vemo, da to ne drži, po drugi strani E. M. Stern $(1997,130)$ ugotavlja, da okrajšava VITR pomeni vitrearius/ria (steklopihalec) in se torej nanaša na steklarja ali steklarko, medtem ko beseda facit (izdelal) neposredno kaže na mojstra, ki je posodo izdelal, in ne na lastnika steklarske delavnice. Sodeč po obliki ohranjenih steklenic iz Linza lahko sklepamo, da je Sentia Secunda delovala v drugi polovici 1. stoletja, njeni izdelki pa postali razširjeni in široko uporabni kot posode za shranjevanje in transport.

\subsection{Nova tehnika - nova odkritja}

Najneposrednejši in najzgodnejši dokaz o pihanju stekla in morda celo o širitvi novoodkrite steklarske tehnike na območju Jadrana brez dvoma predstavljajo oljenke $\mathrm{z}$ upodobitvijo steklarske peči in steklarjev ob njej (Lazar 2004, 28 fig. 15; 2006b, 227). Do sedaj poznamo le tri take najdbe in vse izvirajo z najdišč ob obalah Jadrana. Prva oljenka je bila najdena v prvi 


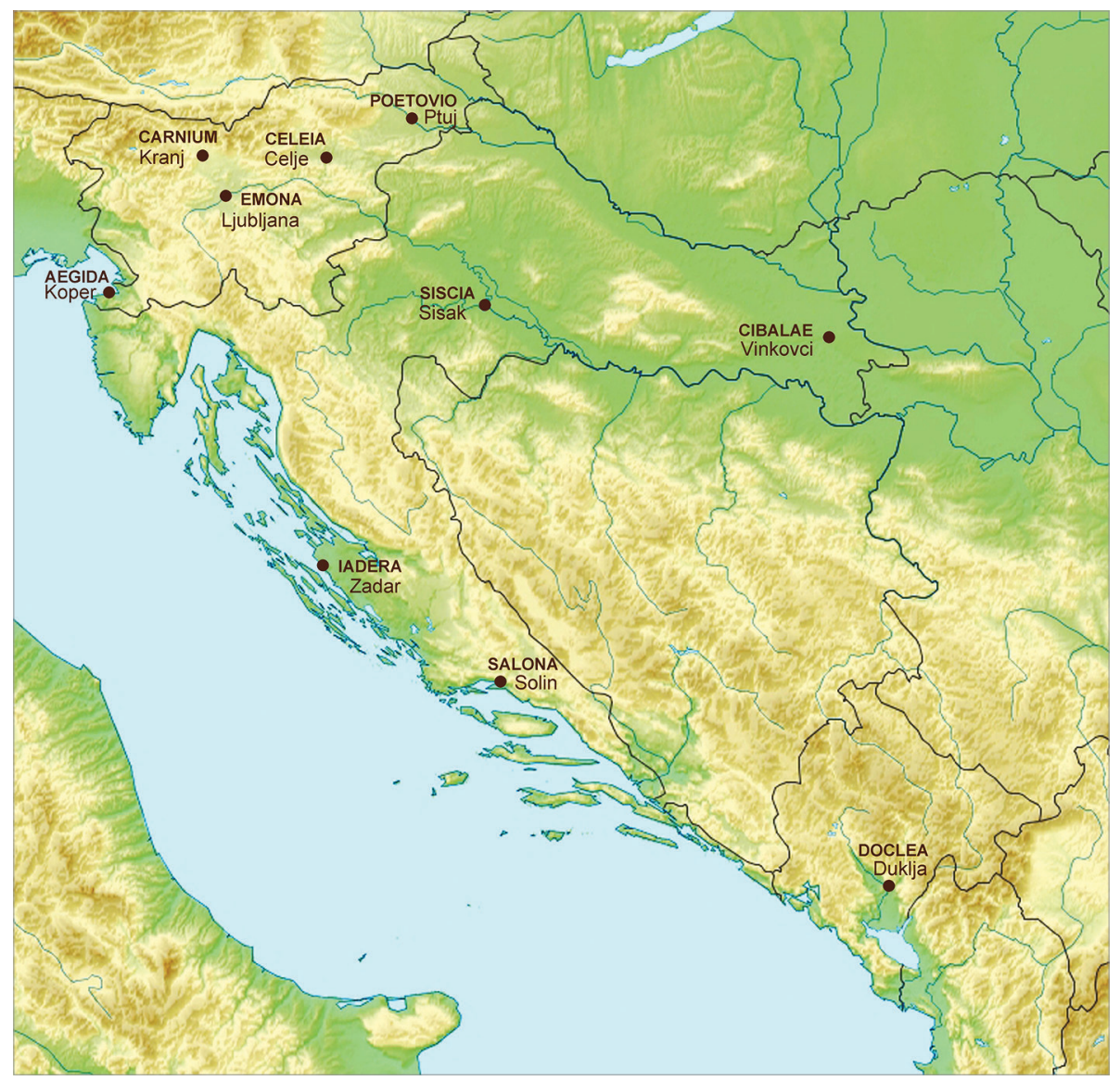

Slika i: Karta področja JV Alp in Jadrana z obravnavanimi najdišči (pripravil Andrej Preložnik)

polovici 20. stoletja v Benkovcu (rimska Asseria) na Hrvaškem (Abramić 1959, 149), druga je bila odkrita v drugi polovici 20. stoletja v bližini Ferrare (Voghenza) v Italiji (Baldoni 1987, 22), najnovejša in najbolje ohranjena najdba pa je oljenka iz Slovenije (Lazar 2006b, 230, sl. 2-3). Primerjava velikosti oljenk in diskov kaže, da sta oljenki iz Ferrare in Spodnjih Škofij (dl. 11,5 in $11,3 \mathrm{~cm}$ ) zelo verjetno nastali $\mathrm{v}$ istem kalupu, medtem ko je bil kalup za oljenko iz Aserije drugačen, saj je imel nad motivom vrezani imeni Athenio in Tre(a)llus (Abramič 1959, 151; dl. oljenke 10,5 cm). Za razliko od prvih dveh, ki sta slučajni najdbi, zadnja oljenka izvira iz groba (gr. 3 - grobna parcela 1, Križišče pri Spodnjih Škofijah, nekaj km od Kopra), datiranega med 40 do 60 n. š. (Novšak, Bekljanov Zidanšek in Žerjal 2019, 166-75). 

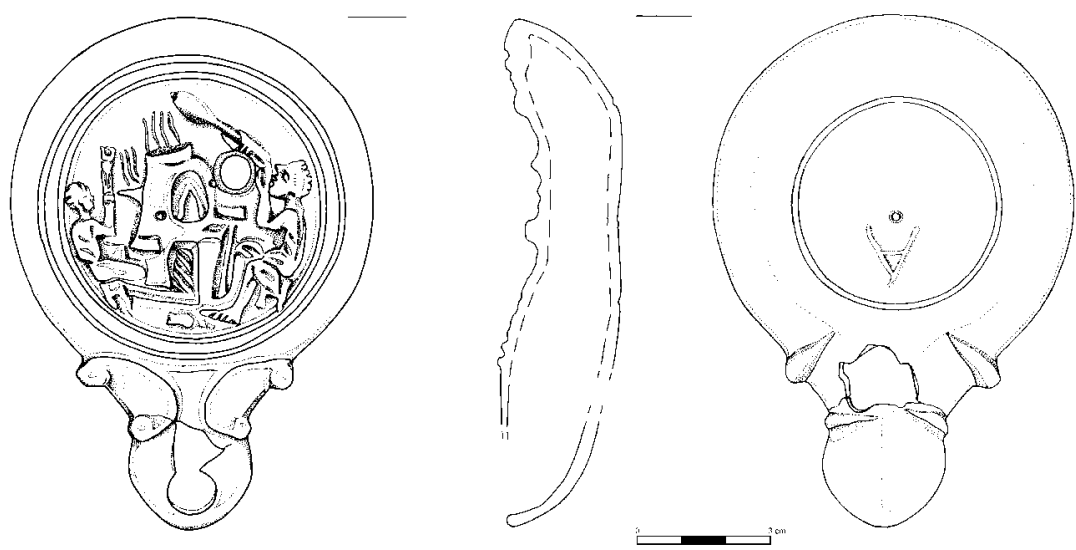

Slika 2: Oljenka z upodobitvijo rimske steklarske peči, Križišče pri Spodnjih Škofijah, risba Jerneja Kobe (hrani Pokrajinski muzej Koper)

Oljenka iz sivo žgane gline sodi v skupino t. i. reliefnih oljenk in pripada tipu Loeschke IV z zaokroženim noskom in volutama ob straneh. Relief (slika 2) predstavlja steklarsko peč in ob njej levo in desno steklarja pri delu. Upodobitev je odlično izdelana in oljenka zelo dobro ohranjena, zato na njej prepoznamo mnoge podrobnosti (Lazar 2006b, 229). Desna figura piha v steklarsko pipo, leva pa ji pomaga ob peči. Osrednji del tvori peč, deljena v dva dela, spodnji služi kot kurišče. V gornjem delu peči je vidna večja polkrožno zaključena odprtina. Uporabljala se je za zajemanje staljenega stekla iz talilnikov in kot delovna odprtina steklarja. Steklar sedi na nizkem stolčku ob peči, oblečen je v kratko tuniko in bos, kar poudarjajo poševni vrezi na nogi. Na tleh ležijo trije predmeti, ki jih lahko interpretiramo kot odpadke, nastale med delom. Oseba ima glavo dvignjeno, usta našobljena in pripravljena za pihanje v cev, ki jo drži pred seboj. Pipa je, če upoštevamo sorazmerja med osebo in orodjem, dolga manj kot meter in precej robustna na pogled. Morda ni kovinska, ampak glinena, kot predlaga E. M. Stern $^{2}$ na osnovi svojih številnih eksperimentov (Stern 1999, 446; 2005, 15-

2 Prvi pihani izdelki so verjetno nastali z uporabo glinenih pip in šele kasneje so razvili kovinske. Nekateri raziskovalci, kot npr. dr. E. M. Stern, menijo, da je bil steklarjem najlaže dostopen material prav glina. Njene lastnosti so dobro poznali, na zalogi je bila v vsaki delavnici. Glina precej slabše prevaja toploto kot kovina, zato je z njo laže delati, posebej če je pipa kratka, npr. 30-60 cm. Izdelava kovinske cevi ni enostavna, glineno pa si lahko izdela steklar sam. Zato ni bilo potrebno investirati v drage kovinske pripomočke, ampak so si lahko orodje izdelali po svojih željah in potrebah. Enostavna izdelava orodja je bila morda tudi eden od vzrokov za bliskovito razširitev nove tehnike (Stern 2005). 
18, sl. 1-5). Pod pipo je okrogla odprtina oljenke za zrak. Figura na levi čepi ob peči, verjetno je mojstrov pomočnik. V rokah ima krajši predmet, ki je postavljen navpično, morda preverja ohlajeno posodo.

$\mathrm{V}$ tem trenutku nimamo dokazov za obstoj lokalne proizvodnje rimskega stekla na obalnem območju ali v zahodni Sloveniji, nedaleč stran pa leži Akvileja, kjer je, kot kažejo najdbe, steklarska delavnica delovala že v 1. stoletju (Mandruzzato in Marcante 2007, 16). Proizvodnja steklenih izdelkov oz. pihanje stekla se je na področju današnje Slovenije razvilo v drugi polovici 1. oziroma na začetku 2. stoletja Najverjetneje so delavnice predvsem pokrivale lokalne potrebe za vsakdanjo rabo. Razvoj obrti je brez dvoma povezan s širitvijo rimske države na ozemlje današnje Slovenije in $\mathrm{z}$ romanizacijo tega prostora.

\subsection{Steklarska proizvodnja v Celeji in Poetovioni}

Najdbe steklarskih peči, talilnikov, staljenega stekla in odpadkov proizvodnje, ki jih poznamo iz Celeje in Poetovione, kažejo, da je bila prav v teh mestih v 1. oziroma 2. stoletju osnovana proizvodnja stekla. Ostanki peči, kosov surovega stekla, odpadki pihanja in uničeni izdelki so tiste najdbe, ki dokazujejo obstoj sekundarne proizvodnje stekla, to je izdelave steklenih posod, v obeh mestih. Obrt je bila odvisna od uvoza surovega stekla, ki so ga pripravili in talili v sredozemskih centrih primarne proizvodnje in nato transportirali do delavnic po imperiju.

Dokazi o proizvodnji stekla v Celeji so bili odkriti pri izkopavanjih leta 1991. Žal ostanki steklarske peči niso bili odkriti, saj so bila izkopavanja omejena na območje gradbenega posega, vendar pa so ostanki steklenih kapelj, niti, koščkov staljenega stekla in odpadki z ustja steklarske pipe neposredni dokazi, da so na tem mestu pihali steklo oz. izdelovali stekleno posodje (Lazar 2003a, 214, sl. 57). Količina odpada je precejšnja, amorfni koščki surovega stekla so pretežno zelenkastega odtenka. Značilni odpadki za dokaz steklarske proizvodnje so kaplje stekla, ki dokazujejo preverjanje viskoznosti, steklene niti, ki nastanejo med delom steklopihača in izdelavo posode, in odpadki z roba steklarske pipe. Ti so na pogled kot slabo narejeno ustje posode, a so najneposrednejši dokaz o uporabi steklarske pipe in pihanju posod. Prav tako pomembni so odpadki slabo izdelanih posod, kot npr. uničeno ustje posode, trakovi, iz katerih so vlekli ročaje, staljeni fragmenti zavrženih delov itd.; nenazadnje je bil v enega od grobov severne nekropole priložen polizdelek skodelice (Lazar 2008, sl. 2-3). Ostanki tan- 

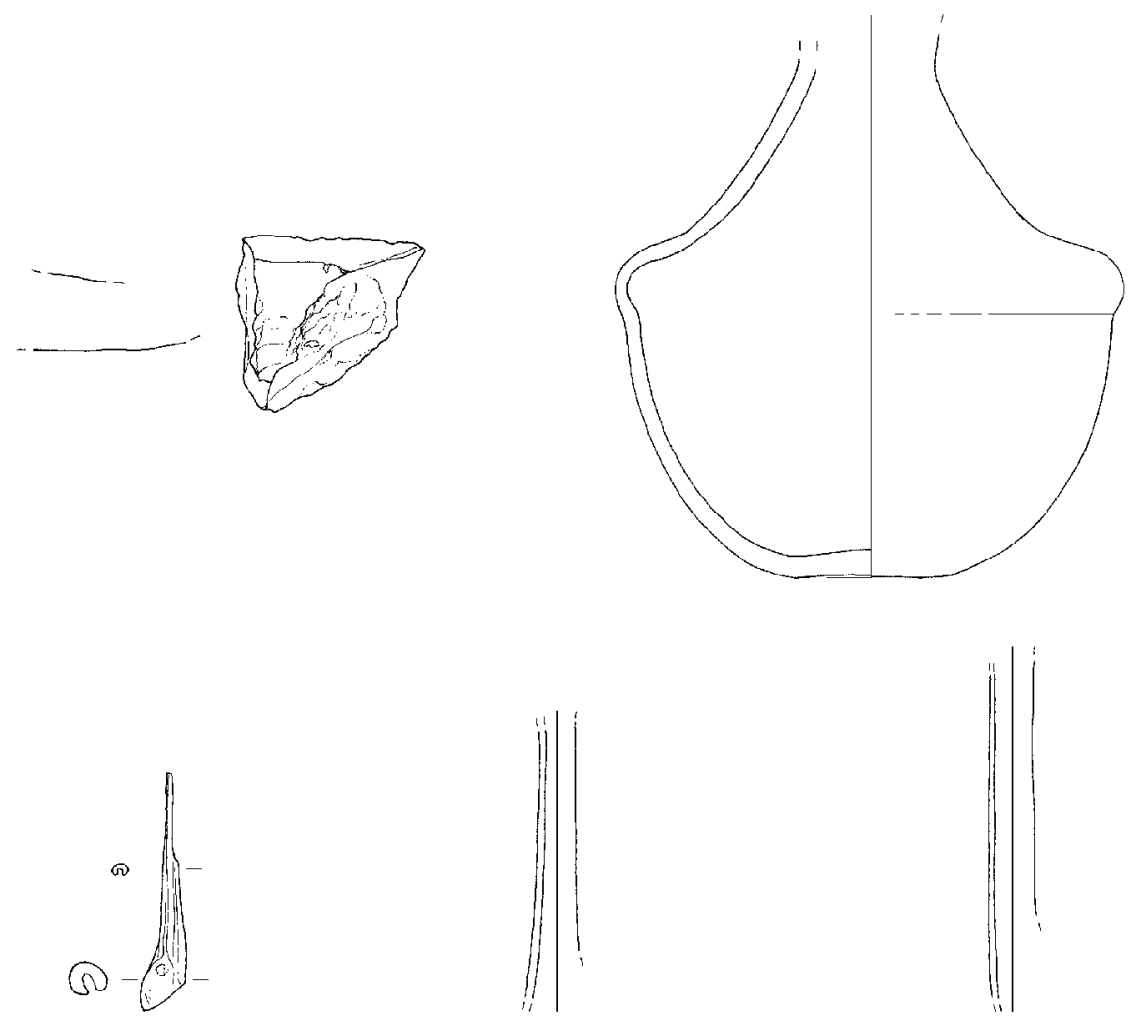

Slika 3: Celje (Celeia) - steklene cevke in polizdelek skodelice iz poznorimskega groba (po Lazar 2008)

ke plasti ali prstana staljenega stekla na dnu balzamarijev in čaš dokazujejo poleg steklarske pipe tudi uporabo prijemalke oz. kovinske palice.

Omeniti velja tudi lego celjske delavnice. Zadnja izkopavanja v Celju v obdobju med letoma 2002 in 2005 so odkrila ostanke večjega obrtnega območja na severnem delu mesta oz. na njegovem robu. Tudi steklarji so si svoj prostor poiskali v tem delu mesta, zaradi uporabe ognja stran od gosto naseljenega mestnega središča, neposredno ob glavni cesti, ki je vodila iz mesta, in v bližini reke, prav tako pomembne transportne poti, tako za dostavo surovin in kurjave kot za izdelke. Prav zadnje raziskave $\mathrm{v}$ severnem delu mesta, $v$ neposredni bližini ostankov delavnice, so prinesle tudi nove dokaze o delovanju steklarjev. $\mathrm{V}$ enem od poznorimskih grobov severne celejske nekropole so bile pridane steklene cevčice in polizdelek, ki dajejo nove podatke o možnih začetkih in času delovanja steklarske delavnice. Upoštevajoč male steklene cevke in koščke surovega dekolorira- 


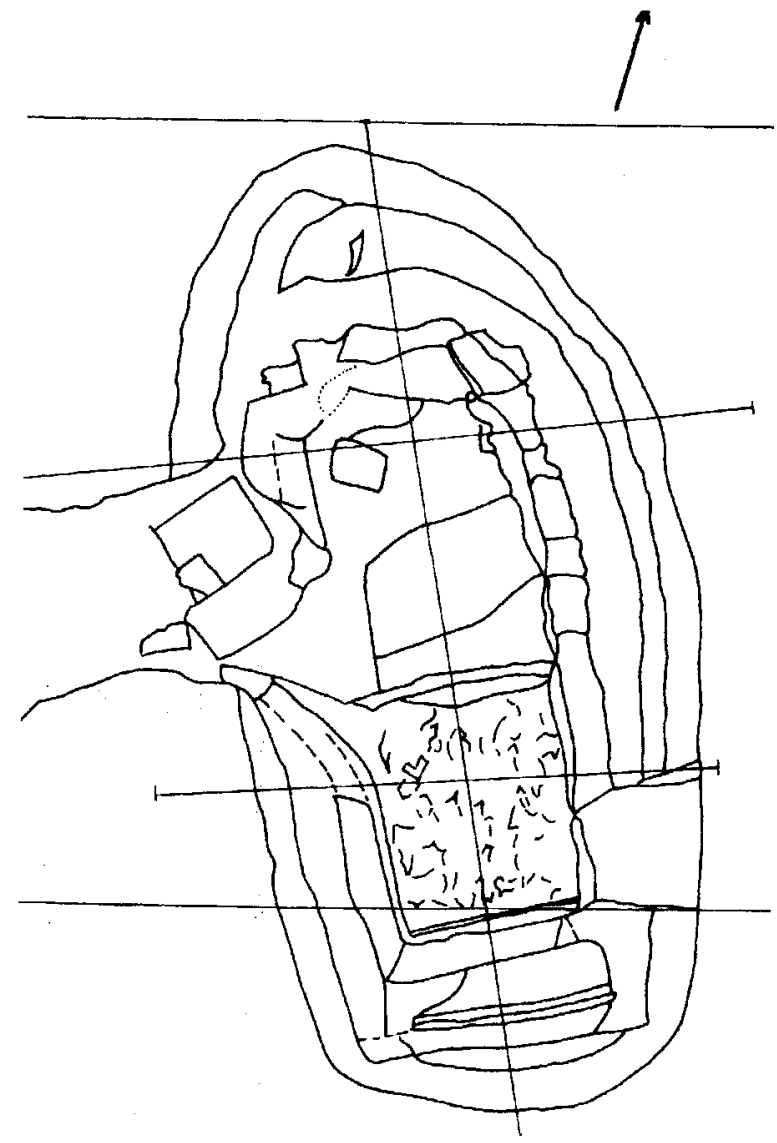

\section{Slika 4: Ptuj (Poetovio) - tloris steklarske peči na parceli Hameršek (po Lazar 2003b)}

nega stekla ter nedokončano polkroglasto skodelico (Isings 96b; slika 3) lahko domnevamo, da se je proizvodnja stekla v mestu začela že v drugi polovici 1. stoletja in je delovala še konec 3. oz. v začetku 4. stoletja (Lazar 2008, 138).

Sodeč po do sedaj znanih najdbah je bila steklarska obrt najrazvitejša oz. najobsežnejša v Poetovioni (Ptuj). Šest steklarskih peči, ostanki talilnikov in steklarski odpad so neposreden dokaz o steklarski proizvodnji v mestu (Lazar 2003a, 219, sl. 61-64; Korošec 2004, 67). Leta 1978 je ekipa ptujskega muzeja v okviru zaščitnih izkopavanja na parceli Hameršek odkrila dve steklarski peči in ostanke tretje. Istega leta so na parceli Preložnik odkrili ostanke še treh peči (Lazar, 2003a, 219). 
Najbolje ohranjeni ostanki peči so bili odkriti na parcel Hameršek in na osnovi tega lahko podamo rekonstrukcijo njihovega izgleda. ${ }^{3}$ Peči so bile podolgovato ovalnega tlorisa, z zunanjimi merami 2,05 $\mathrm{m} \mathrm{x} \mathrm{1,00} \mathrm{m}$ in notranjimi $0,70 \mathrm{~m} \times 1,30 \mathrm{~m}$. Zidovi so bili iz opek različnih oblik in na notranji strani zamazani $z$ več plastmi gline, posebej debel je bil sloj na notranji strani (Lazar 2003b, 78, sl. 1). Notranjost peči je bila z zidom deljena $\mathrm{v}$ dva dela, eden je bil namenjen kurišču, drugi pa je bil delovni prostor. Neposredno ob kuriščnem delu je ležal kanal, ki se je uporabljal kot manipulativni prostor za kurjenje peči (slika 4). Kuriščni del je bil nekoliko večji od delovnega prostora in se je polkrožno zaključil (vel. o,60 x 0,40 cm). Delovni prostor je bil kvadratnega tlorisa. Kako je izgledal gornji del peči, lahko samo ugibamo. Zaradi zaščitnega posega je bil raziskan le majhen del okrog peči in na osnovi tega ne moremo sklepati, ali odkriti ostanki predstavljajo celotno delavnico ali pa del večjega obrtnega kompleksa steklarjev. Potrdimo lahko samo to, da so peči ležale v obrtnem predelu Poetovione na Spodnji Hajdini, kjer so med drugim obratovale tudi peči za keramiko in opeko (Jevremov 1985, 419; Horvat idr. 2003, 160). Številne druge posamične najdbe pa hkrati kažejo, da steklarji niso delovali le v tem delu mesta (Lazar 2003a, 221). Med njimi velja izpostaviti predvsem kose talilnikov z ostanki staljenega stekla na notranji strani in robovih ustja. Njihove oblike kažejo, da so za taljenje uporabili na vretenu izdelane posode, nizke lonce enakih oblik, kot jih poznamo med ptujsko kuhinjsko keramiko (Istenič 1999, 137, sl. 130).

Trenutno še ne obstaja natančna opredelitev steklarskih peči s kvadratno obliko delovnega prostora, kot jih poznamo na Ptuju. B. Lepri in L. Saguí $(2017,170)$ domnevata, da so podolgovate strukture (2 m dolžine in $1 \mathrm{~m}$ širine) uporabljali le za ponovno taljenje surovine in morda še za dodajanje novega surovega stekla; bolj razširjene peči okroglega tlorisa pa naj bi bile v uporabi predvsem za pihanje steklenih posod. Primerjava tovrstnih struktur z nekaterimi drugimi primeri na najdiščih, kot so npr. Besançon (Munier 2003; Munier in Brkojewitsch 2003; Foy 2010), Plaudren (Triste 2008), Augst (Fischer 2009, datirano 130 do 160 n. š.), Ulpia Oescus (Bolgarija, Kabakčieva 1987, zadnja četrtina 3. in prva polovica 4. stoletja) in kompleksi steklarskih peči v Nemčiji (Köln, van Geesbergen 1999, 1089, 120, 1.-2. stoletje; kompleks Hambacher Forst, Gaitzsch idr. 2000, 105-6, 
$162-63,168 ; 4$. stoletje), potrjuje njune domneve in interpretacijo (Lepri in Saguí 2017, 172).

Ostanki izdelkov, ki naj bi nastajali v ptujskih delavnicah, niso prav številni. Glede na ohranjene odlomke in odpad lahko domnevamo, da so izdelovali kvadratne in cilindrične steklenice $\mathrm{v}$ več velikostih, cilindrične čaše in balzamarije s stopničasto razširjenim vratom, posebej pogost pa je bil tudi okras nataljenih niti po vratu in ostenju (Lazar 2003a, 230).

Spremljevalno keramično gradivo in steklene najdbe, odkrite ob steklarskih pečeh, kažejo, da so steklarske delavnice obratovale v 2. in 3. stoletju. Najdbe iz 1. stoletja so preskromne, da bi razmišljali o zgodnejšem razvoju te obrti v Poetovioni.

Lahko pa na osnovi dokaj obsežnega naselbinskega in grobnega sklopa steklenih najdb ocenjujemo, kako se je uporaba stekla in steklenega posodja v mestu razvijala in spreminjala. Steklenih izdelkov iz prve polovice 1. stoletja je med gradivom relativno malo, njihovo število in raznolikost oblik močno porasteta konec 1. stoletja, in sicer za 300 \% (Lazar 2001, 34). Gre pretežno za izdelke za vsakdanjo uporabo. Večina oblik je v uporabi še v naslednjem stoletju, ko se jim pridružijo še nove oblike, nove tehnike krašenja ter kakovostni importirani izdelki. Do velike spremembe pride v 3 . stoletju, ko se razpon oblik močno skrči, nato pa se v 4. stoletju oblike stekla omejijo pretežno na posode za pitje. Zanimivo pa je, da kljub majhnemu številu oblik in količini steklenega posodja slednjega še vedno redno in $\mathrm{v}$ precejšnji količini prilagajo v grobove, kar na nek način odraža in potrjuje še vedno živahen utrip mesta v pozni antiki.

\subsection{Problem interpretacije najdb v Emoni in Kranju}

Izpostaviti velja še dve najdišči, za kateri se je domnevala proizvodnja rimskega stekla, a je na osnovi najdb in sodobnega poznavanja obrti ne moremo potrditi (podrobneje Lazar 2003a, 216). Zaradi velikega števila steklenih pridatkov v emonskih grobovih je bila ideja o mogoči lokalni proizvodnji v Emoni zapisana že pred pol stoletja (Plesničar 1976, 35). Nato so izkopavanja v insuli XXXI v SZ delu mesta odkrila ostanke, ki so jih interpretirali kot steklarsko delavnico (Plesničar Gec 1981, 136). V prostoru velikosti 4,1 x 4,7 $\mathrm{m}$, ki je bil s slabo ohranjenimi zidovi deljen v tri dele, so naleteli na ostanke, ki naj bi pripadali steklarski delavnici (odlomki opek, posod, okenskega stekla, staljenega stekla). Žal je bila ta najmlajša faza arhitekturnega kompleksa najslabše ohranjena in pokrita samo z ostanki ruševine. Verjetno je bil ta del stavbe uničen in nato zravnan (Plesničar Gec 1981, 139). 
Ob natančnejšem pregledu objavljenega gradiva $\mathrm{z}$ izkopavanj $\mathrm{v}$ insuli XXXI moramo izraziti dvom, ali je na odkritem mestu res delovala steklarska delavnica. Skromnost ostankov arhitekture peči ni presenetljiva. Zanimivo pa je, da na opekah ni ostankov steklene žlindre oziroma staljenega stekla, ampak se opek držijo koščki stekla in odlomki posod. Do tega lahko pride tudi pri požaru in zatorej ti ostanki niso nujno del uničene steklarske peči. Ostalo gradivo so bili pretežno odlomki steklenih posod in okenskega stekla, nič pa ne govori v prid obdelavi stekla. Med odlomki posod prevladujejo čaše oblike Isings 96 , ki so gladke ali okrašene $\mathrm{z}$ modrimi kapljami, plitve skodele z gubami (Isings 117) in steklene svetilke s čepki (Lazar 2003, 198, oblika 9.3.1.). Plast je bila na osnovi novčnih najdb in stekla datirana na konec 4. in začetek 5. stoletja (Plesničar Gec 1981, 142).

Ostanke uničenih posod in okenskega stekla lahko interpretiramo na več načinov. Morda gre za zbiranje odpadnega stekla za ponovno uporabo, navado, ki je bila uveljavljena in jo poznamo $z$ več rimskih najdišč (Price 1991, 23). Gradivo kaže časovno enotnost in majhno raznolikost, zato lahko pomislimo tudi na prodajalno stekla. $\mathrm{V}$ neposredni bližini so delovale tudi terme (insula XXXII) in morda so bile prav one glavni odjemalec. S tem izpostavljamo več možnih interpretacij najdb iz insule XXXI, neposredne dokaze o delovanju steklarjev pa moramo še odkriti.

Med zaščitnimi izkopavanji v Kranju ob gradu Kieselstein leta 1998 so arheologi naleteli na zanimive strukture, ki so jih interpretirali kot ostanke poznoantične steklarske delavnice oz. dveh steklarskih peči (Sagadin 2004, 107). Na površini 7 x 13 m so odkrili dve okrogli jami. Premer prve je bil 1,92,1 m (gl. $1 \mathrm{~m}$ ), druge pa 2-2,2 m (gl. o,6 m). Vkopani sta bili v glino in na notranji strani ometani. Večja jama je imela na $Z$ strani razširitev za kurišče, zapolnjeno s plastjo žganine. Zapolnjena je bila s kamni, na površini nekaterih je bila plast steklastega sloja, zaradi izpostavljenosti veliki vročini. Med jamama je bila ploščad premera $1 \mathrm{~m}$, utrjena $\mathrm{z}$ malto in zamejena $\mathrm{s}$ kamenjem. Približno meter od prve jame je ležal plitev bazen (vel. 2,1 x 1,2 $\mathrm{m})$, ki je bil delno zapolnjen $\mathrm{z}$ apnencem in ostanki školjk.

Med drobnimi najdbami je bilo veliko odlomkov stekla, pretežno ustja in dna čaš na nogi, mnoge so bile poškodovane v ognju. Na osnovi keramičnega gradiva in stekla so kompleks datirali v 6. stoletje (Sagadin 2004, 110).

Čeprav kompleks v Kranju še ni bil v celoti objavljen, želimo ponovno opozoriti na problem njegove interpretacije (Lazar 2003a, 217). Na najdišču in ob t. i. pečeh ni bilo najdb, značilnih za obdelavo stekla, deformi- 
rane posode so bile uničene zaradi izpostavljenosti ognju in niso kazale, da gre za zavržene izdelke delavnice. Jame so bile na notranji strani ometane, enako je bil ometan manipulativni prostor. Pri sedaj poznanih steklarskih pečeh te podrobnosti ni nikjer, povsod so premazane $\mathrm{z}$ več plastmi gline. Prav tako je vprašljiv različen nivo manipulativnega prostora in osrednjega dela peči. Pri steklarskih pečeh je to navadno izenačeno, da upravljanje $s$ pečjo teče nemoteno.

Razlaga, da se je ena peč uporabljala za proizvodnjo, druga pa za ohlajanje posod, je vprašljiva. Razdalja med njima je namreč več kot meter ali dva. Rimske peči so imele prostor za ohlajanje v sklopu same peči ali pa v peči v neposredni bližini. Tako se je posoda lahko takoj oz. samo s zasukom steklarja odložila za ohlajanje, da je proces tekel počasi in nemoteno (Foy in Nenna 2001, 48-55). Prenos pravkar izdelane posode v nekaj metrov oddaljeno peč za ohlajanje bi povzročil prehitro hlajenje stekla na površini, napetosti zaradi temperaturne razlike bi povzročilo pokanje in lomljenje izdelkov (Price 1991, 25).

Glede na ogled terena med izkopavanji in opisane strukture lahko brez dvoma ugotovimo, da na tem najdišču ne gre za ostanke steklarskih peči. Glede na velikost in gradnjo bi jih bilo prej mogoče interpretirati kot apnenice oz. peči za žganje apna; kar nekaj jih poznamo tudi pri nas (Tušek 1984; Novšak, Bekljanov Zidanšek in Žerjal 2019, 81).

\subsection{Hrvaška - lokalna proizvodnja v Panoniji in Dalmaciji}

V sosednjih pokrajinah je bila glede na trenutno stanje raziskav rimska steklarska obrt razvita v Gleisdorfu v Avstriji (Fuchs 1980), na območju severne Italije (Buora 1997, 23; Maccabruni 2004, 33; Mandruzzato in Marcante 2007, 16) ter v Siskiji (Siscia - Sisak, Burkowsky 1999; Fadić 2004, 96 sl. 1-2; Leljak in Lazar 2014, 117) in Saloni (Solin, Dalmacija, Buljevič 2005, 93) na Hrvaškem. Prav tako je bila z arheološkimi odkritji na Jadranu potrjena trgovina s surovim steklom; na rimski potopljeni ladji z Mljeta je tovor poleg ostalega vseboval veliko količino surovega stekla (Radić in Jurišić 1993, 113).

Za območje hrvaškega dela province Panonije ugotavljamo, da so bili na več najdiščih ohranjeni elementi, ki odpirajo vprašanje možnega obstoja lokalne proizvodnje (Leljak in Lazar 2014, 115), to so npr. Siscia (Sisak), Cibalae (Vinkovci) in Štrbinci. Najdbe vključujejo surovo steklo, odkrito $\mathrm{v}$ reki, tlorise peči in verjetne lokalne oblike izdelkov. Vendar ostaja še veliko vprašanj, povezanih $\mathrm{z}$ lokalno steklarsko proizvodnjo $\mathrm{v}$ severnem delu Hrvaške. Opredelitev temeljev peči, odkritih v Sisku, kot steklarskih 
je po našem mnenju še vedno nekoliko vprašljiva. Samo tloris peči, brez kakršnihkoli spremljajočih najdb in situ, povezanih s proizvodnjo stekla, še ne more biti nedvoumen dokaz, da gre za steklarsko peč.

Neposredni arheološki dokazi o obdelavi stekla (Leljak in Lazar 2014, 130 in op. 36) na najdišču niso bili odkriti; dokler teh dokazov ni, ne moremo nedvoumno govoriti o steklarski proizvodnji na področju južnega dela province Panonije. Verjetnost obstaja, ni pa nedvoumno dokazana $\mathrm{z}$ najdbami.

Na drugi strani arheološke najdbe iz Dalmacije obstoj lokalne proizvodnje stekla potrjujejo ne samo z ostanki verjetne steklarske peči (Auth 1975), ampak tudi epigrafski podatki oz. najdbe (Buljević 2005, 9, sl. 6). V Saloni so ostanke steklarske peči odkrili v sedemdesetih letih prejšnjega stoletja, ležala je severno od kurije. Toda začetek obratovanja oz. delovanja peči žal ni natančno časovno opredeljen; datiran je v obdobje od 1. do 3. stoletja (Auth 1975, 147; Clairmont in von Gonzenbach 1975, 58-63, 230, pl. 4. 8. 63). Najdbo pa dopolnjujejo drugi dokazi o delovanju steklarjev. Na odlomku sarkofaga s salonitanske nekropole Manastirine je ohranjeno ime ste-

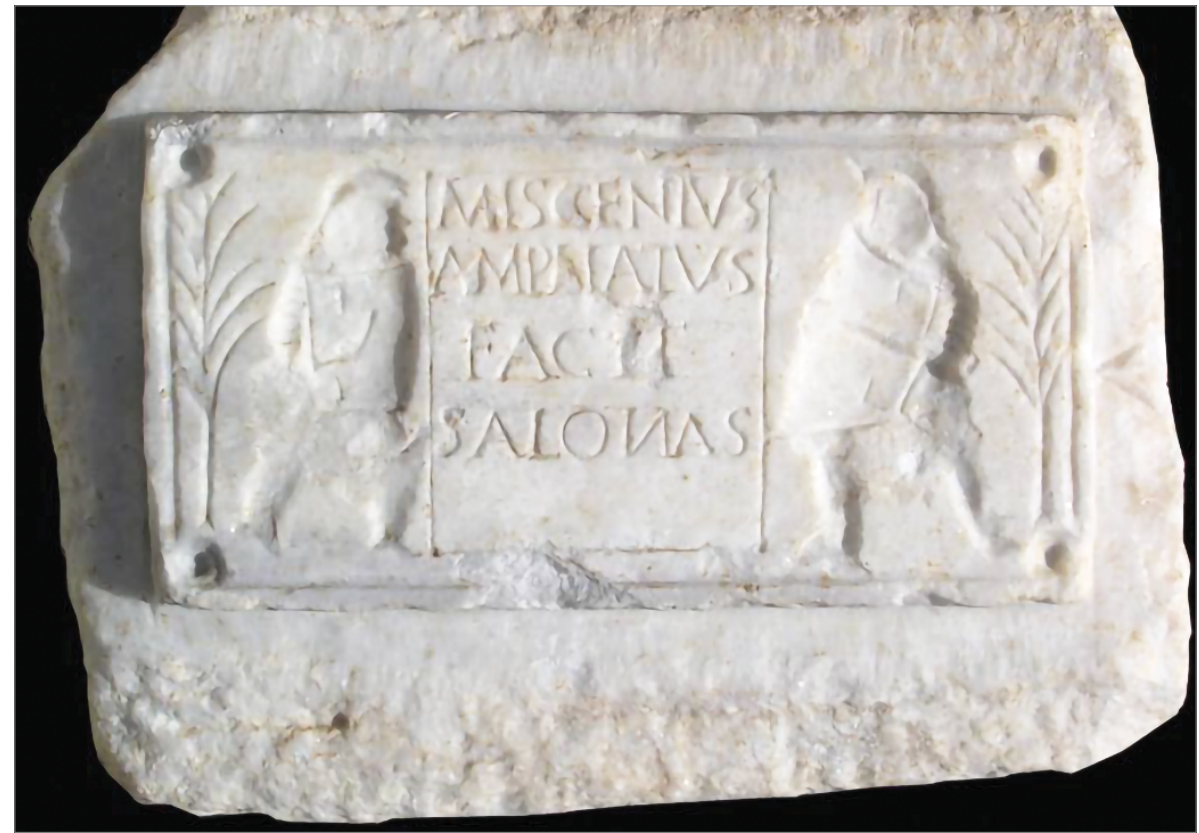

Slika s: Solin (Salona, Hrvaška) - marmorni kalup za dno steklenice z napisom Miscenius Ampliatusfacit Salonas (Arheološki muzej Split; po Buljević 2004) 
klarja Paschasius oz. Pascasius (Egger 1926, 99; Šašel 1986, 285, št. 2487). Z jugovzhodne nekropole v Saloni pa je od leta 1884 znan marmorni kalup z imenom Miscenius Ampliatus (Buljević 2004, 194, sl. 1, 2). Najdbo so dolgo časa interpretirali kot kalup za izdelavo slavnostnih kruhkov, Z. Buljević pa jo je nazadnje pravilno opredelila kot kalup za dno večje kvadratne steklenice $(2004,193)$. Poleg imena mojstra ali lastnika, ki sporoča, da je izdelek Miscenius Ampliatus facit Salonas, je v reliefu tudi podoba gladiatorjev (slika 5).

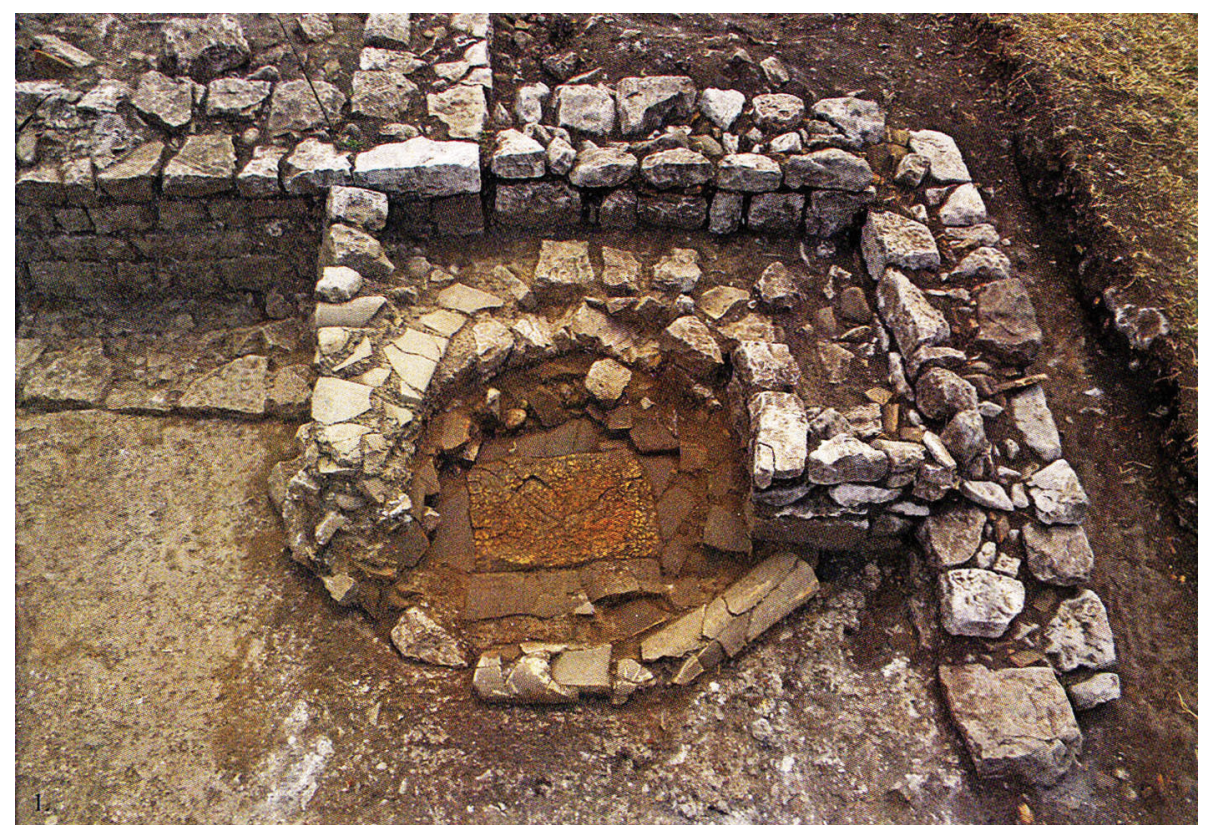

Slika 6: Duklja (Doclea, Črna gora) - peč v prostoru Is/IX med izkopavanji, foto M. Živanovič (po Živanović 2oI4)

Številne najdbe steklenega posodja $\mathrm{z}$ območja Zadra (Iader) in nekatere posebne oblike, ki se pojavljajo predvsem na tem področju oz. na predelu Liburnije, so podlaga za hipotezo, da je tudi v Zadru delovala steklarska delavnica (Fadić 2004, 101). Žal obrat ali drugi dokazi o sekundarni steklarski proizvodnji na tem področju do sedaj niso bili odkriti in številne najdbe steklenega posodja so za sedaj bolj odraz stanja raziskav nekropol antične Liburnije. 


\subsection{Nova odkritja v Črni gori - Doclea}

Za konec velja omeniti še zadnja pomembna odkritja iz rimske Dokleje (Doclea - Duklja) v Črni gori, ki jih je objavil kolega Miloš Živanović (2014, 47). V teku izkopavanj v letih 2002 do 2013 je bil odkrit obrtni predel v poznoantičnem mestu, ki je nastal na opuščenem in zapuščenem predelu mestnega kapitolija. Središče rimskega mesta Doclea je v poznorimski dobi izgubilo svoj pomen in zato so ta predel zasedli obrtniki ter tu postavili delavnice za predelavo železa in obdelavo stekla. Mestne komunikacije so območje še vedno povezovale $\mathrm{z}$ mestoma Dyrrhachium (Drač, Albanija) in Salona (Solin, Hrvaška).

Steklarski obrat je obsegal večje območje, ki še ni v celoti raziskano. Tekom 4. stoletja so stare stavbe podrli in predel očistili ter na tem mestu zgradili steklarsko delavnico, ki jo datirajo na konec 4 . in začetek 5 . stoletja (Živanović 2014, 130). Odkriti so bili trije prostori s posamičnimi pečmi (3/IX, 15/IX, 12/IX; slika 6) in domnevajo, da so nastale oz. delovale v časovnem zaporedju.

Peči so bile zgrajene v kotu prostora, ob njih so odkrili številne odpadke obdelave stekla, talilnike in fragmente stekla. Prostori so bili dokaj veliki, kar kaže na dobro organiziran obrat, morda so bili nekateri posebej namenjeni shranjevanju in celo okraševanju (Živanović 2014, 101, 130, pl. 42, 49).

Odkrite oblike posod so bile pretežno namenjene pitju in shranjevanju tekočin, najštevilnejše med njimi pa so polkroglaste čaše oblike Isings 96, pretežno datirane v 4. in 5. stoletje (Isings 1959; Živanović 2014, 130). $\mathrm{V}$ enem od prostorov so naleteli na veliko število odlomkov steklenih zapestnic in jagod, zato domnevajo, da je tu obstajala tudi proizvodnja t. i. črnega stekla ${ }^{4}$ (soba IX, Živanović 2014, 131). Trenutne najdbe kažejo, da je steklarski obrat v prvih desetletjih 5. stoletja prenehal delovati; izdelkov, ki bi bili značilni za 6. in 7. stoletje, na najdišču niso odkrili (Živanović 2014, 98, 131).

Podobni obrtni centri poznorimske dobe, ki govorijo o preobrazbi urbanih centrov številnih rimskih mest, so znani tudi iz mest Romuliana in Ulpiana v provinci Meziji in sodijo v čas 4. in 5. stoletja (Janković 1983, 102-3; Parović in Pešikan 1991, 33-60). Osnovani so bili znotraj zaprtega mestnega predela in so izkoristili nekdanjo oz. ohranjeno infrastrukturo. Poznorimske steklarske delavnice so bile v tem delu imperija odkrite tudi v 
Sirmiju (Sirmium - Sremska Mitrovica), v Iustiniana Prima (Caričin Grad), posamične najdbe so znane tudi iz Skodra (Skadar; Milošević 1976, 102-8; Ivanišević in Stamenković 2010, 39-52; Hoxha 2003, 99).

\section{Sklep}

Arheološke raziskave in analize steklarske proizvodnje v antiki prinašajo vedno nove podatke, tako glede proizvodnje stekla kot surovine kot sekundarne proizvodnje širom imperija (Nenna 2007). Pregled znanih in novih najdb območja JV Alp in Jadrana, povezanih z rimsko steklarsko proizvodnjo, prav tako odkriva nova dejstva; ta odražajo živahne in tesne trgovske stike, ki so se $\mathrm{v}$ času pozne republike in zgodnjega imperija razvili med jadranskim območjem in njegovim zaledjem (Aquileia - Emona - Celeia Poetovio; Aquileia - Emona - Siscia; Aquileia - Pula - Iader), prav tako pa s področjem vzhodnega Sredozemlja, središčem razvoja in napredka antičnega steklarstva.

Dediščina proizvodnje stekla na območju današnje Slovenije in njenega sosedstva je izjemno bogata in raznolika, vendar v mnogih primerih še ne $v$ celoti ovrednotena, zato raziskave in obdelava novoodkritega gradiva tečejo dalje. Poudariti pa velja, da po propadu Rimskega imperija nimamo dokazov o neposrednem nadaljevanju steklarske proizvodnje v mlajša obdobja. V samostanu Žiče, ustanovljenem ok. leta 116o, so v bogati knjižnici med drugim hranili tudi knjige o obdelavi in proizvodnji stekla (Lazar 20o3b, 81). Kdaj in kako pa se je obrt v srednjem veku ponovno razvila, ostaja odprto.

Prispevek je nastal na podlagi raziskav, sofinanciranih iz projekta »Izvedba poizkopavalne obdelave arhiva najdišča Ribnica za izvedena zaščitna arheološka izkopavanja« financiranega s strani DARS in ZVKDS (ZVKDS PG-10-40/2018).

\section{Literatura}

Abramić, M. 1959. »Eine römische Lampe mit Darstellung des Glasblasens.« Bonner Jahrbücher 159: 149-51.

Auth, H. S. 1975. "Roman Glass.« V Excavations at Salona, Yugoslavia (19691972), ur. C. W. Clairmont, 145-75. Park Ridge, NJ: Noyes Press. 
Baldoni, D. 1987. »Una lucerna romana con raffigurazione di officina vetraria: alcune considerazioni sulla lavorazione del vetro soffiato nell'antichità.« Journal of Glass Studies 29: 22-29.

Bass, G. F. 1986. »A Bronze Age Shipwreck at Ulu Burun (Kaş): 1984 Campaign.« American Journal of Archaeology 90: 269-96.

Blečić Kavur, M., in B. Kavur. 2017. "Many Shades of Translucent: Amphoriskos Shaped Glass-Beads from Vičja luka/Mnoge nijanse prozirnog: staklene perle u obliku amforiska iz Vičje luke.«Vjesnik za arheologiju i historiju dalmatinsku 110 (1): 93-11.

Buljević, Z. 2004. "Salonitanski kalup s prikazom gladijatora/Salona Mold with Image of Gladiators.« Opuscula Archaeologica 28: 193-202.

Buljević, Z. 2005. »Tragovi staklara u rimskoj provinciji Dalmaciji/Traces of Glassmakers in Roman Province of Dalmatia."Vjesnik za arheologiju $i$ povijest dalmatinsku 98: 93-106.

Buora, M. 1997. »Una produzione artigianale di un vetraio Sevegliano (agro di Aquileia, Italia settentrionale) nel IV sec. D. C.« Journal of Glass Studies 39: $23-31$.

Burkowsky, Z. 1999. Sisak u prapovijesti, antici i starohrvatskom dobu. Sisak: Arheološki muzej.

Calvi, C. 1969. I vetri romani del Museo di Aquileia. Oglej: Associazione nazionale per Aquileia.

Calvi di Coenzo, L.1996. „Da Venezia all' Africa ...e ritorno.« Alte Vitrie 3: 8-11.

Clairmont, C. W., in V. von Gonzenbach. 1975. »The Excavations: The Workshop Area."V Excavations at Salona, Yugoslavia (1969-1972), ur. C. W. Clairmont, 56-63. Park Ridge, NJ: Noyes Press.

Dular, A. 1991. Prazgodovinska grobišča v okolici Vinjega vrha nad Belo Cerkvijo. Katalogi in monografije 26. Ljubljana: Narodni muzej Slovenije.

Egger, R. 1926. Der altchristliche Friedhof Manastirine, Nach dem Materiale Fr. Bulić. Forschungen in Salona II. Dunaj.

Fadić, I. 2004. "Antičke staklarske radionice u Hrvatskoj/Ancient Glass Workshops in the Territory of Modern Croatia.« V Drobci antičnega stekla/Fragments of Ancient Glass. Annales Mediterranea, ur. I. Lazar, 95106. Koper: ZRS Koper.

Fischer, A. 2009. Vorsicht Glas! Die römischen Glasmanufakturen von Kaiseraugst. Forschungen in Augst 37. Augst: Augusta Raurica.

Foy, D. 2010. „L'implantation des ateliers de verriers en Gaule: centre surbains, péri-urbains et ruraux."V Aspects de l'artisanat en milieu urbain: Gaule 
et Occident romain, Actes du colloque international d'Autun 20-22 septembre 2007, ur. P. Chardron-Picault, 345-61. Dijon: RAE.

Foy, D., in M.-D. Nenna. 2001. Tout feu, tout sable. Mille ans de verre antique dans le Midi de la France. Exhibition catalogue. Marseille: Musées de Marseille

Franjić, A., I. Freestone, D. Günther in B. Križ. 2020. »Stranded in Novo mesto: The Analysis of Iron Age Glass Beads from Lower Carniola, Slovenia.« $\mathrm{V}$ Annales du zıe Congrès de l'AIHV, v tisku. Istanbul: AIHV.

Fuchs, G. 1980. »Die römerzeitlicher Gräberfelder von Flavia Solva.« Doktorska disertacija, Universitat Graz.

Gabrovec, S. 1987. "Jugoistočnoalpska regija sa zapadnom Panonijom Dolenjska grupa.« V A. Benac, Praistorija jugoslovenskih zemalja V, Željezno doba, 29-119. Sarajevo: Akademija nauka i umjetnosti Bosne i Hercegovine.

Gaitzsch, W., A.-B. Follmann-Schulz, K.-H. Wedepohl, G. Hartmann in U. Tegtmeier. 2000. „Spätrömische Glashütten im Hambacher Forst Produktionsort der ECVA-Fasskrüge. Archäologische und naturwissenschaftliche Untersuchungen.«Bonner Jahrbücher 200: 83-241.

van Geesbergen, D. 1999. »Les ateliers de verriers dans le nord de la Gaule et en Rhénanie (Ier-4e siècle après J.-C.).«V Artisanat et productions artisanales en milieu rural dans les provinces du nord-ouest de l'Empire romain. Actes du colloque d'Erpeldange 1999, ur. M. Polfer, 105-24. Montagnac: Éditions M. Mergoil.

Haevernick, T. E. 1958. »Hallstatt-Tassen.«Jahrbuch des Römisch-Germanischen Zentralmuseums Mainz 5: 8-17.

Haevernick, T. E. 1959. »Beiträge zur Geschichte des antiken Glases I: Zu den Glasbügelfibeln.« Jahrbuch des Römisch-Germanischen Zentralmuseums Mainz 6: 57-63.

Haevernick, T. E. 1974. "Zu den Glasperlen in Slowenien.« Situla 14/15: 61-65.

Harden, D. B. 1981. Catalogue of Greek and Roman Glass in the British Museum, Volume I. London: British Museum.

Horvat, J., M. Lovenjak, A. Dolenc Vičič, M. Lubšina Tušek, M. Tomanič Jevremov in Z. Šubic. 2003. "Poetovio - development and topography.« V The Autonomous Towns of Noricum and Pannonia, Pannonia I. Situla 41, ur. M. Šašel Kos in P. Scherrer, 153-70. Ljubljana: Narodni muzej Slovenije. Hoxha, G. 2003. Scodra dhë Praevalis ne antikitetin e vonë. Shkodër: Camaj-Pipa 
Ignatiadou, D. 2016. »Le verre incolore: Une renaissance macédonienne.« V La Macédoine du VIe siècle avant J.-C. à la conquête romaine. Formation et rayonnement culturels d'une monarchie grecque, ur. K. Chryssanthaki-Nagle, S. Descamps-Lequime in A.-M. Guimier-Sorbets, 129-42. Pariz: Éditions de Boccard.

Istenič, J. 1999. Poetovio, zahodna grobišča I Poetovio, the Western Cemeteries I. Katalogi in monografije 32. Ljubljana: Narodni muzej Slovenije.

Ivanišević, V., in S. Stamenković. 2010. »Glass Workshop from Caričin Grad (Iustiniana Prima)." V Glass along the Silk Road from 200 BC to AD 10oo, ur. B. Zorn in A. Hilgner, 39-52. Mainz: Romisch-Germanisches Zentralmuseum.

Janković, Ć. 1983. »U sutonu antike.« V Gamzigrad, kasnoantički carski dvorac, ur. S. Čelić, 98-119. Beograd: Srpska akademija nauka i umetnosti.

Jevremov, B. 1985. "Novosti o obrtniških dejavnostih in nekaj drobcev iz arheoloških izkopavanj v letih 1970-1980."Ptujski zbornik 5: 419-30.

Kabakčieva, G. 1987. »Produzione vetraria di Oescus: Note Preliminary.» Ratiariensia 3-4: 171-76.

Kastelic, J. 1960. »Nov tip halštatskega diadema v Sloveniji.« Situla 1: 3-26.

Korošec, P. 2004. »Sledovi steklarske delavnice v Rabeljčji vasi na Ptuju/The Remains of a Glass-Workshop at Rabeljčja vas in Ptuj.«V Drobci antičnega stekla/Fragments of Ancient Glass. Annales Mediterranea, ur. I. Lazar, 67-70. Koper: ZRS Koper.

Križ, B. 1995. Novo mesto pred Iliri. Katalog razstave. Novo mesto: Dolenjski muzej.

Križ, B. 1997. Kapiteljska njiva.. Katalog razstave. Novo mesto: Dolenjski muzej.

Križ, B., in P. Turk 2003. Bernstein- und Glasschmuck aus Novo mesto, Slowenien. Ausstellungskatalog. Schriftenreihe des Keltenmuseums Hochdorf, Enz 5. Eberdingen: Keltenmuseum Hochdorf/Enz.

Lazar, I. 2001. »Roman Glass from Poetovio - New Information about Forms and Local Production.« Archaeologia Poetovionensis 2: 33-40.

Lazar, I. 2003a. Rimsko steklo Slovenije/The Roman Glass of Slovenia. Opera Instituti Archaeologici Sloveniae 7. Ljubljana: ZRC SAZU.

Lazar, I. 2003b. "Roman Glass production in Slovenia." V Annales $d u$ 16e Congrès de l'AIHV, 79-84. Nottingham: AIHV.

Lazar, I. 2004. »Odsevi davnine - Antično steklo v Sloveniji/Spiegelungen der Vorzeit - Antikes Glas in Slowenien.« V Rimljani - steklo, glina, kamen/Die Römer - Glas, Ton, Stein, ur. I. Lazar, 11-81. Celje; Ptuj; Maribor: Pokrajinski muzej Celje. 
Lazar, I. 2005. »Fragment of the Base of the Bottle with the Inscription SENTIA SECUNDA.«Bulletin Instrumentum 21: 41-42.

Lazar, I. 2006a. »Glass Finds in Slovenia and Neighbouring Areas.« Journal of Roman Archaeology 19 (1): 329-42.

Lazar, I. 2006b. „An Oil Lamp from Slovenia Depicting a Roman Glass Furnace.« Vjesnik za arheologiju i povijest dalmatinsku 99: 227-34.

Lazar, I. 2008. «New Evidence about Roman Glass Production in Celeia (Noricum). ZZeitschrift fürSchweizerische Archäologie und Kunstgeschichte $65(1 / 2): 137-40$.

Lazar, I. 2019. "Črno steklo, da ali ne? Rimski vrč iz groba 4/1988 na ptujski obvoznici in nove najdbe posod iz na pogled črnega stekla.« Zbornik Pokrajinskega muzeja Ptuj 6: 29-43.

Lazar, I., 2020. »Romula - Ribnica." V Mala naselja rimske dobe v Sloveniji, Opera Instituti archaeologici Sloveniae 40, ur. J. Horvat, I. Lazar in A. Gaspari, 387-402. Ljubljana: ZRC SAZU.

Leljak, M., in I. Lazar. 2014. »Roman Glass Workshops in the Croatian Part of the Province of Pannonia.« Vjesnik arheološkog muzeja u Zagrebu 46 (1): $115-33$.

Lepri, B., in L. Saguí. 2017. »Mapping Glass Production in Italy: Looking through the $1^{\text {st }}$ Millennium AD.«V Annales du $20 e$ Congrès de l'AIHV 20, 16874. Fribourg, Romont: AIHV.

Maccabruni, C. 2004. "La ricerca sulla produzione vetraria antica in area norditalica."V Drobci antičnega stekla/Fragments of Ancient Glass, Annales Mediterranea, ur. I. Lazar, 25-42. Koper: ZRS Koper.

Mandruzzato, L., in A. Marcante. 2007. Vetri antiche del Museo Archeologico Nazionale di Aquileia. CCV Friuli Venezia Giulia 3. Trst: AIHV Italia.

Milošević, P. 1976. »Radionice stakla u Sirmijumu.« Arheološki vestnik 25: $102-8$.

Munier, C. 2003. »Un atelier de verrier du IIe siècle à Besançon.« V Coeur de verre: production et diffusion du verre antique, ur. D. Foy, 46-51. Gollion: Infolio.

Munier, C., in G. Brkojewitsch. 2003. „Premiers éléments relatifs à la découverte récente d'un atelier de verrier antique à Besançon."Échanges et commerce du verre dans le monde antique. Monographies Instrumentum 23, ur. D. Foy in M.-D. Nenna, 321-37. Montagnac: Éditions M. Mergoil.

Nenna, M.-D. 2007. »Production et commerce du verre à l'époque impériale: nouvelles découvertes et problématiques.« Facta 1: 125-47. 
Nenna, M.-D. 2008. "Nouveaux acquis sur la production et le commerce du verre antique entre Orient et Occident." Zeitschrift für Schweizerische Archäologie und Kunstgeschichte 65: 61-66.

Novšak, M., I. Bekljanov Zidanšek in T. Žerjal 2019. Križišče pri Spodnjih Škofijah. AAS 81. Ljubljana: ZVKDS.

Parović Pešikan, M. 1991. »Kompleks metalurških peći na Ulpijani.« Zbornik radova Muzeja rudarstva i metalurgije u Boru 5-6: 33-65.

Plesničar Gec, L. 1976. »Steklene zajemalke iz severnega emonskega grobišča.» Arheološki vestnik 25: 35-37.

Plesničar Gec, L. 1981. »The Production of Glass at Emona.« Archaeologia Iugoslavica 20-21: 136-42.

Price, J. 1991. »The Evidence for the Production of Glass in Roman Britain.« $\mathrm{V}$ Ateliers des verriers de l'Antiquite a la periode Pre-industrielle, 4e Rencontre de l'AFAV, 23-27. Rouen: AFAV.

Radić, I., in M. Jurišić 1993. "Das antike Schiffswrack von Mljet, Kroatien.« Germania 71: 113-38.

Rustoiu, A. 2015. »Amphora-Shaped Glass and Coral Beads: Distant Cultural Connections in the Carpathian Basin at the Beginning of the Late Iron Age." Archäologisches Korrespondenzblatt 45 (3): 365-77.

Sagadin, M. 2004. »Poznoantična steklarska delavnica (?) v Kranju.« V Drobci antičnega stekla/Fragments of Ancient Glass. Annales Mediterranea, ur. I. Lazar, 107-14. Koper: ZRS Koper.

Schwanzar, C. 2003. »Römischer Fernhandel.«V Woraufwir stehen: Archäologie in Oberösterreich, ur. J. Leskovar, C. Schwanzar in G. Winkler, 329-34. Weitra: Bibliothek der Provinz.

Stare, F. 1975. Dobova. Brežice: Posavski muzej.

Stern, E. M. 1997. "Neikais - A Woman Glass Blower of the First Century A.D.« V Komos. Festschrift für Thuri Lorenz zum 65. Geburtstag, ur. G. Erath, M. Lehner in G. Schwarz, 129-32. Dunaj: Phoibus.

Stern, E. M. 1999. "Roman Glassblowing in a Cultural Context."American Journal of Archaeology 103: 441-84.

Stern, E. M. 2005. „À la recherche de la première canne à souffler.« Bulletin Instrumentum 21: 15-18.

Triste, A. 2008. "L'atelier de verriers antique de Kerfloc'h à Plaudren (Morbihan)." Aremorica: Études sur l'ouest de la Gaule romaine 2: 87-103.

Živanović, M. 2014. Zanatske radionice kasnoantičke Dokleje/Craft Workshops in Late Roman Doclea. Podgorica: JU Muzeji i galerije Podgorice. 


\section{Summary}

\section{Ancient glass production in the Southeastern Alps and Eastern Adriatic}

In the southeastern Alpine region, the first known glass finds are from the Urnfield Culture period. In the Early Iron Age, the area witnessed an extraordinary diversification of glass decoration in colour and form as well as the appearance of the first glass vessels. New analyses of the material give evidence about the long-distance trade with glass and glass products from the Mediterranean. The Roman period brought innovations that developed in glass craft in the Hellenistic and Early Roman period. The earliest evidence of glassblowing in the Adriatic area is represented by oil lamps depicting a glass furnace. The best-preserved lamp was found lately in Slovenia in a Roman grave in Križišče near Spodnje Škofije in the vicinity of Koper. Roman glass production developed in Celeia (Celje) and Poetovio (Ptuj) as early as the end of the 1st or the beginning of the 2nd century. Glass production in neighbouring areas is confirmed to have existed in Gleisdorf (Austria) and at Siscia (Sisak) and Salona (Solin, Dalmatia) in Croatia. The archaeological finds from Dalmatia consist also of epigraphic evidence. A sarcophagus fragment from the necropolis at Manastirine in Salona revealed the name of a glassmaker Paschasius or Pascasius, while the southeastern necropolis yielded a marble mould with the inscription Miscenius Ampliatus facit Salonas. The latest discoveries in the area are known from the Roman town of Doclea (Duklja, Montenegro), where three Late Roman glass furnaces were discovered. 